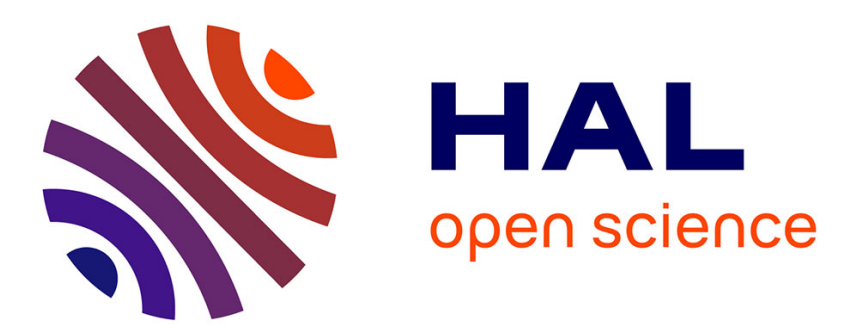

\title{
Land abandonment and the spreading of the forest in the Eastern French Pyrenees in the nineteenth to twentieth centuries
}

\author{
Jean-Paul Métailié, Martin Paegelow
}

\section{- To cite this version:}

Jean-Paul Métailié, Martin Paegelow. Land abandonment and the spreading of the forest in the Eastern French Pyrenees in the nineteenth to twentieth centuries. Recent dynamics of the mediterranean vegetation and landscape, Wiley, pp.219-236, 2004. halshs-01061768

\section{HAL Id: halshs-01061768 \\ https://shs.hal.science/halshs-01061768}

Submitted on 8 Sep 2014

HAL is a multi-disciplinary open access archive for the deposit and dissemination of scientific research documents, whether they are published or not. The documents may come from teaching and research institutions in France or abroad, or from public or private research centers.
L'archive ouverte pluridisciplinaire HAL, est destinée au dépôt et à la diffusion de documents scientifiques de niveau recherche, publiés ou non, émanant des établissements d'enseignement et de recherche français ou étrangers, des laboratoires publics ou privés. 


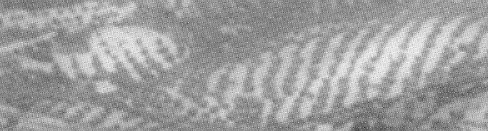

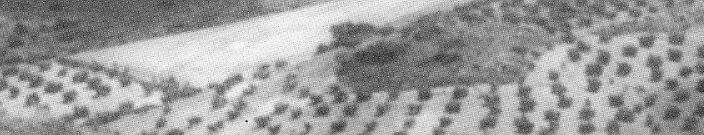

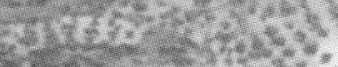

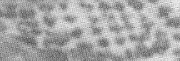

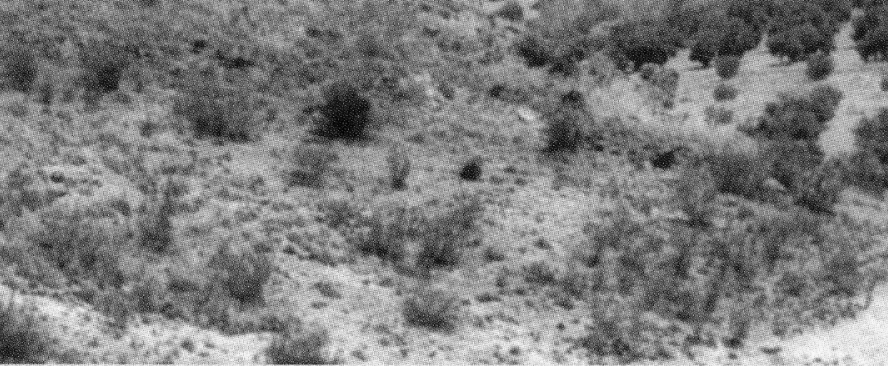

Recent Dynamics of the Mediterranean

Vegetation and Landscape

Editors: S. Mazzoleni, G. di Pasquale, M. Mulligan, P. di Martino, F. Rego

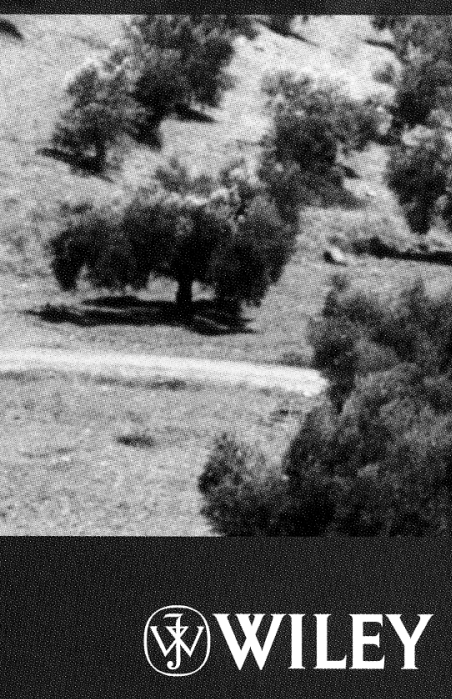




\title{
Land Abandonment and the Spreading of the Forest in the Eastern French Pyrenées in the Nineteenth to Twentieth Centuries
}

\author{
JEAN PAUL METAILIÉ AND MARTIN PAEGELOW \\ GEODE UMR 5602 CNRS, Université de Toulouse "Le Mirail", France
}

\subsection{INTRODUCTION}

Forests have spread throughout the French Mediterranean hills and mountains, which have now become some of the most afforested regions in France. According to the National Forest Survey of 1996, the forest ratio in this area was between 50 and $65 \%$, reaching $77 \%$ in the Cevennes. The eastern French Pyrenees has recently been affected by dramatic land abandonment and various afforestation dynamics. This chapter reports on the spread of Pinus uncinata, which is colonising large areas of the eastern Pyrenees at an altitude from $1300 \mathrm{~m}$ up to $2400 \mathrm{~m}$. Two studies are presented, with different time scales and different methodologies:

1. a long-term history of a forest and pastoral landscape in the upper valley of the Ariège (in the massif of Aston);

2. an analysis of recent dynamics in cultivated areas, by means of a Geographic Information System (GIS) in the Upper Conflent (valleys of the Garrotxes).

\subsection{THE END OF THE METALLURGICAL AND AGRO-PASTORAL LANDSCAPE}

The population peak in the eastern Pyrenees was reached between 1840 and 1880 , at the time of the most highly developed agro-sylvo-pastoral mountain landscape. Since this period, a rapid rural decline has occurred because of many factors: the sudden stop of Catalan metallurgy, an agricultural and pastoral crisis (stagnation of sheep farming, potato disease, cholera), and the transformation from temporary migration of the rural population into definitive migration to the cities.

From the Middle Ages to the nineteenth century, the Ariège and Catalonia was a very important centre for iron metallurgy, based on an abundant and high quality iron ore, and a continually improved technology: the Catalan forge. This is a water-powered ironworks, using the process of direct reduction of iron without casting (low furnace). The Catalan forge was an improvement on medieval ironworks, which did not use bellows for ventilation but wind created by a waterfall in a blast pump (the Pyrenean trompe). Charcoal production for the forges had a strong impact on the forests and provoked the growth of broadleaved coppices (Fagus sylvatica L., Quercus pubescens Willd. and Quercus petraea M. Liebl.), and the regression of coniferous species (mainly Abies alba Mill. and Pinus sylvestris L.). Overexploitation of woodlands for charcoal and stock farming resulted in a landscape of degraded and scattered coppices, and the disappearance of entire woodlands, particularly the mountain and sub-alpine Abies-Pinus forests. 


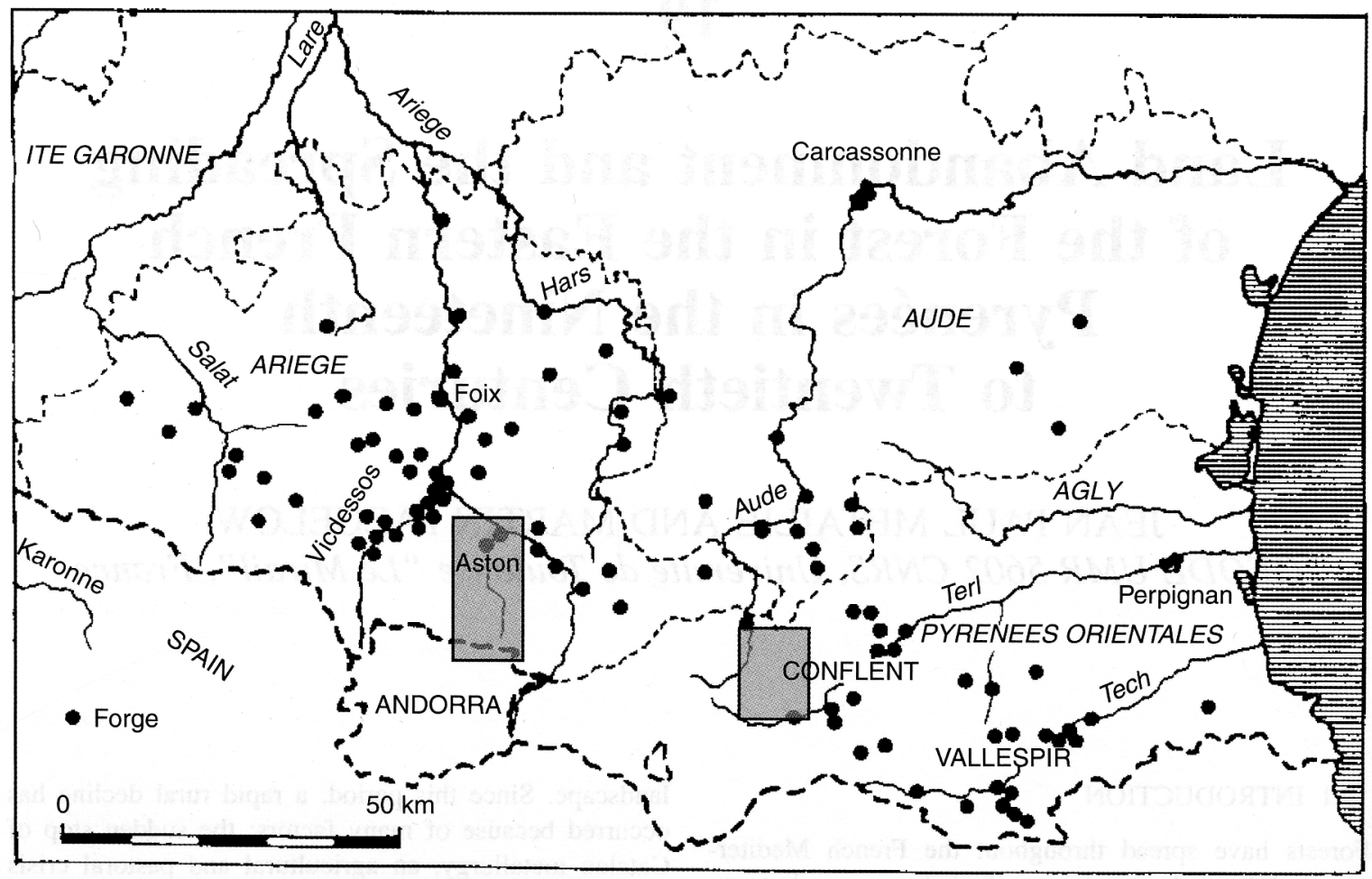

Figure 19.1 Locality of the study areas in the valleys of Ariège and Garrotxes. Dots show the sites of Catalan forges for iron extraction in the nineteenth century

Metallurgical activity continually increased from the Middle Ages to the nineteenth century. In spite of wood shortage, growth intensified during the first half of the nineteenth century, linked to high iron consumption, technological improvement of the Catalan process and to large-scale charcoal production. The number of forges during this century reached 100 to 110 in the departments of Ariège, Aude and Pyrénées-Orientales (Bonhôte and Cantelaube, 1989; Bonhôte and Fruhauf, 1990; Izard, 1994) (Figure 19.1). The Second Empire was the last prosperous period of Catalan metallurgy, which then began to be affected by competition with the blast furnace iron and steel industry, and rapidly declined. The last Catalan forge stopped working in the Ariège in 1884 and around 1888 in the PyrénéesOrientales.

The effect of the end of charcoal production was instantaneous on the forest landscapes: coppices began to grow and thicken or were turned into high stands by foresters; fir spontaneously colonised large woods where it had once been eliminated; heliophilous species such as Betula verrucosa or $P$. uncinata began to colonise the degraded woodlands. These forest dynamics were accelerated by the agro-pastoral crisis and the spread of fallow land.

The peak population level was reached in the Ariège around 1846, and around 1886 in Catalonia, but rural depopulation began as early as 1820 or 1830 in some overpopulated valleys. The decrease in rural population accelerated after World War I and during the 1950s and 1960s. From the 1970s, the decrease slowed or stopped and the population even increased in some valleys, especially in Catalan valleys attractive to tourists (Cerdagne, Capcir) (Figure 19.2). However, the global population curve was sustained by the importance of small cities, and is not representative of the villages' evolution: in many cases, the total decrease in population since the nineteenth century reached $90 \%$.

Landscape dynamics cannot be linked exclusively to demography. This is clear in the Ariège: the first aerial photographs, in 1942, show an agro-pastoral landscape, which is very similar to that of the previous century: fallow lands were mainly fringe lands, cultivated during times of overpopulation; there were large meadows on northern slopes, cultivation on sunny slopes and the edges of woodlands were not colonised by scrub. Until 

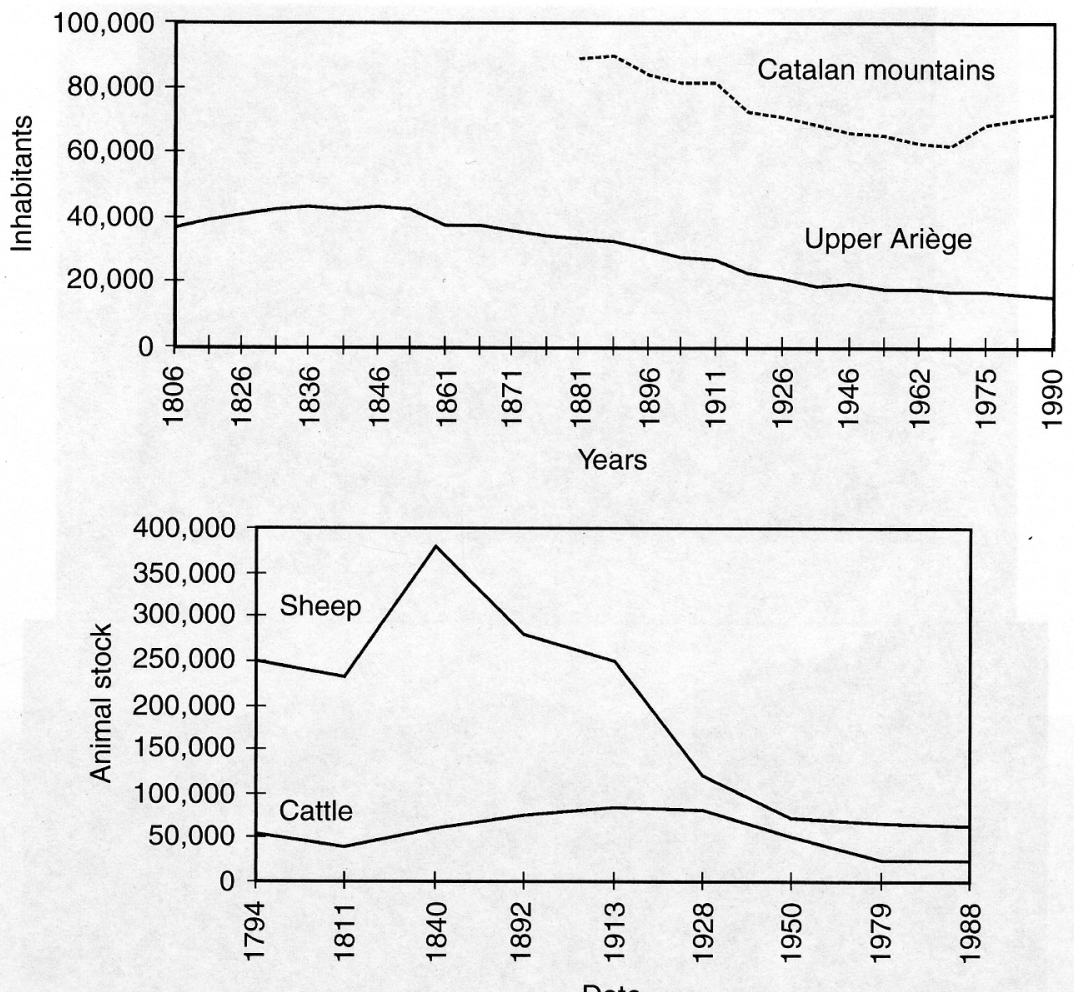

Date

Figure 19.2 (a) Evolution of population in the Upper Ariège (cantons of Ax, Les Cabannes, Vicdessos and Tarascon) and the Catalan mountains (all mountain cantons); (b) evolution of stock farming in the Ariège mountains

the 1930s, rural emigration mainly affected the poorest classes of the mountain population (farm workers, younger sons without property, etc.), small artisans and workers in light and metallurgical industries. This emigration had little consequence for the landscape, because the main farms were maintained. Moreover, the stock was increasing and the composition was changing. Sheep farming decreased rapidly because it was linked to a small local community of peasants using common lands and long-range transhumance. The importance of cattle farming increased because it was more adapted to larger farms and to new economic circumstances, and did not provoke the abandonment but the transformation of cultivated land into meadows (Figure 19.2) ${ }^{1}$.

After World War II, emigration changed: farmers left the villages, land abandonment started and a rapid spread

\footnotetext{
${ }^{1}$ Interpretation of these agricultural statistics requires care, in particular for the nineteenth century: the method of statistics could change, the size of the flocks was changing during the year (it was at a maximum in autumn before the fairs), and so on. However, up to 1900 , the statistics show a clear tendency.
}

of fallow lands began. The surface area of the farms and the flocks' size increased at the same time, but not enough to compensate for the diminution of the number of farmers. During recent years, the stabilisation or increase in the rural population (a general trend in France) did not slow this disappearance of farmers. In some valleys of the Upper Ariège (the cantons of $\mathrm{Ax}$, Les Cabannes, Tarascon), the rate of decrease has been 30 to $40 \%$ during the last 15 years. At present, in the Ariège and Catalan mountains, there are many villages with only one farmer, and many others without any.

Fallow lands and the spread of forests are a direct consequence of the end of the traditional agro-sylvopastoral system. The rapidity of landscape change is clearly shown by diachronic analysis of photographic archives (Métailié, 1997). Two examples are shown, in Figures 19.3 and 19.4, for the upper valley of the Aude and the valley of Carol.

The first area, Rouze, is located at an altitude of $900 \mathrm{~m}$ on the sunny slope of the Donezan, a canton of the Ariège in the upper Aude valley. The photo of 1935 shows the cultivated areas around the village 


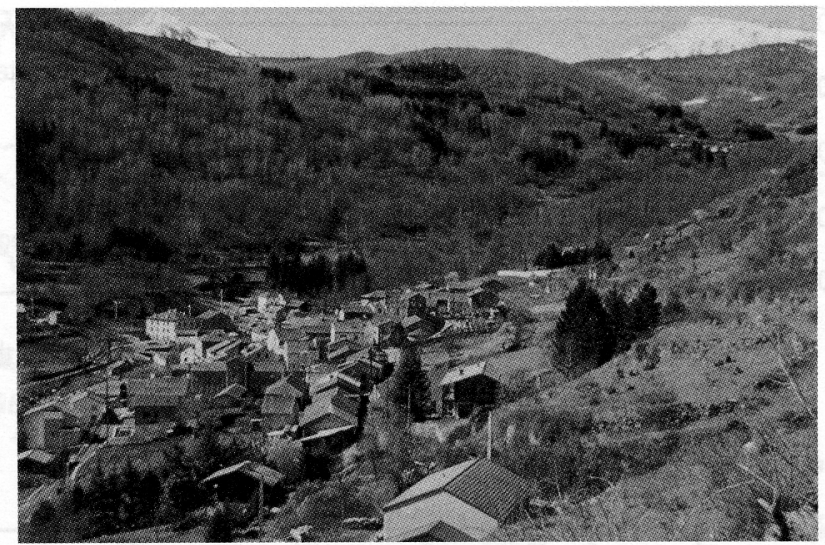

(a)

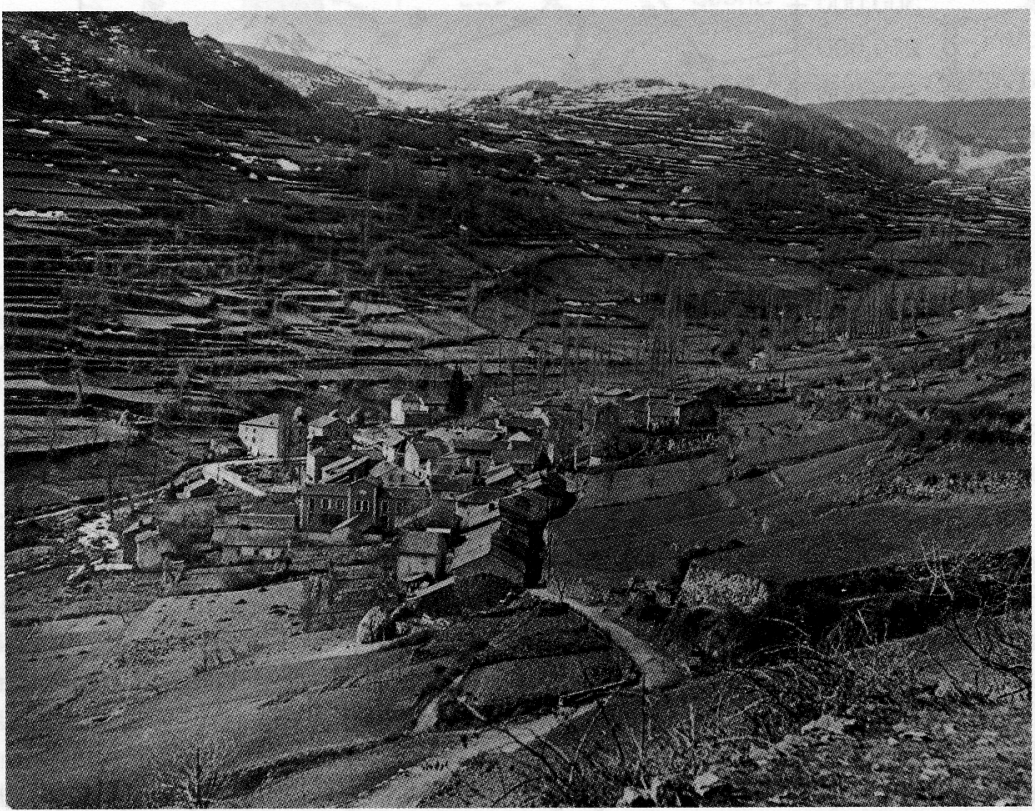

(b)

Figure 19.3 Rouze (Ariège, upper valley of Aude): (a) March 1995 (Source: J.P. Métailié); (b) March 1935 (Source: H. Gaussen)

with terraces and a bocage with Fraxinus excelsior and Populus italica. The evolution over the last sixty years is typical of the dynamics in the eastern Pyrenees: land abandonment on the wet northern slopes, colonisation by Fraxinus, Betula and Fagus on the upper slopes near the woodlands. Artificial conifer afforestation occurred on private properties with non-local species (Picea excelsa, Douglas fir, Larix decidua). At the opposite end, on the sunny slopes, forest dynamics have been halted by soil drought and fire management; here, the vegetation of fallow lands is composed of dry grassland and bracken (Brachypodium pinnatum, Pteridium aquilinum), thick scrub (Prunus avium, Corylus avellana) and broom (here: Cytisus purgans with Cistus laurifolius). On the upper slopes (not in the photo), oak scrub and coppices $(Q$. petraea) are thicker. The evolution of the village structure is also significant: the building of tourist houses on the sunny slope and a big cowshed by one of the last farmers (far left) affects the use of space. 


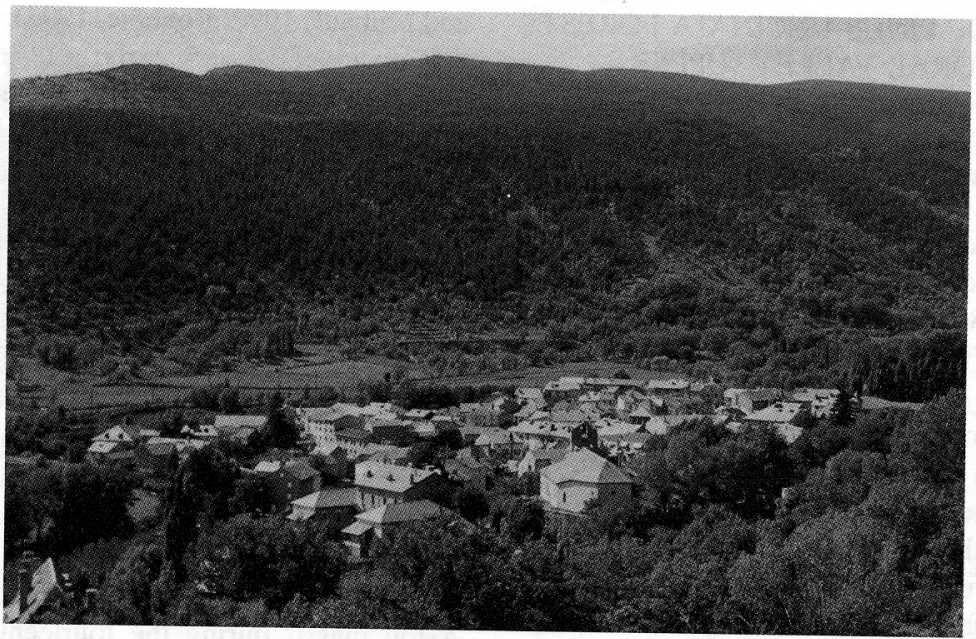

(a)

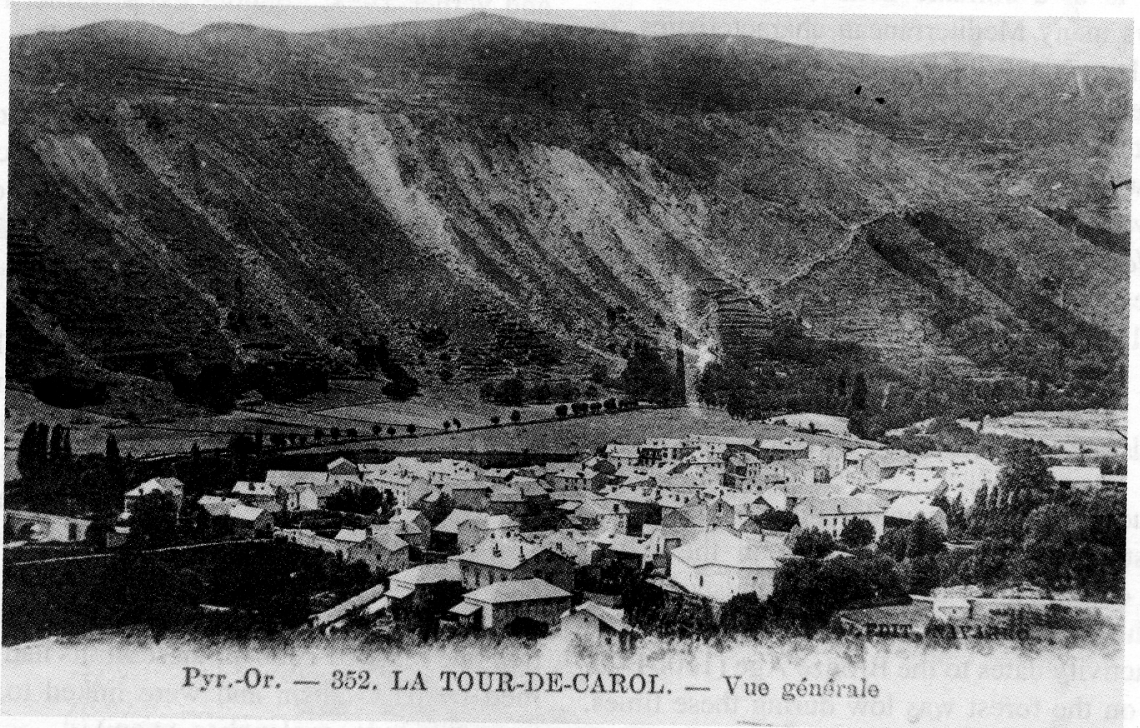

(b)

Figure 19.4 La Tour-de-Carol (Pyrénées-Orientales, Carol valley, (a) August 1985 (Source: J.P. Métailié); (b) circa 1910 (postcard)

The second example (Figure 19.4) is the northern slope of the Carol valley, at an altitude between $1250 \mathrm{~m}$ and $2200 \mathrm{~m}$ (the summits are in the background). The border between France and Spain is situated at $1500 \mathrm{~m}$ on the slope, on the edge of a moraine. In 1910, the side of the moraine facing the village was used as autumn and spring pasture, with some terraces for cultivation, but the heavy pastoral pressure on the brittle glacial deposits provoked erosion. In the background, the agropastoral lands of Guils de Cerdaña, a Spanish border village, were totally deforested, except maybe the upper slopes (pine woods are visible on the aerial photos of 1942). Afforestation was rapid from 1940 onwards and, by 1985 , all of the cultivated lands and pastures had been colonised by a thick $P$. uncinata woodland, while the lower slope, near the alluvial plain, had been colonised by Fraxinus and Betula. The spread of those homogeneous coniferous woodlands led to high vulnerability to fire: in 1986, a large part of the pine woods in the upper Carol valley were burnt. 
19.3 DYNAMICS OF PINUS UNCINATA FORESTS IN A SYLVO-PASTORAL VALLEY (UPPER ARIĖGE, ASTON)

\subsubsection{The study area}

"Aston" is the name of a village and of a great crystalline massif of the Pyrenees axial zone, characterised by wide plateaus, between 1800 and 2200 masl, and deep glacial valleys. The Aston valley is $20-\mathrm{km}$ long, and extends from Andorra to the Ariège river. The limits of the study area are mainly historical and correspond to the ancient domains of Gudanes and Luzenac: its borders are, to the south, Andorra, at between 2260 and 2900 masl; to the north the Ariège valley, between 550 and 600 masl; the eastern limit is the canton of Ax-les-Thermes; and the western is the canton of Vicdessos.

Situated on the Atlantic side of the Pyrenées, the Upper Ariège is in a climatic zone of transition and the flora shows many Mediterranean characteristics. In the lower valley, stands of Quercus ilex are located on the calcareous sunny slopes, whereas $P$. uncinata is abundant at higher altitudes, especially on the high plateau. The woods on the rocky and sheltered slopes of the Aston valley are mainly composed of $Q$. petraea and Tilia cordata, up to the altitude of $1600 \mathrm{~m}$. On the northern slopes, the beech-fir mountain forest stops at an altitude of $1700 \mathrm{~m}$, which is the upper limit for beech.

\subsubsection{The history of metallurgy in the area}

Numerous studies have been undertaken on the environmental history of Ariège, especially in the Aston valley, which enables us to describe the landscape evolution from the beginning of human colonisation. The first pastoral activity dates to the Bronze Age (1500 BC). The pressure on the forest was low during these times, as the first shepherds only crossed the wide mountain forest to reach the high pastures. Woodlands were composed of fir up to 1800 to $1900 \mathrm{~m}$ and pines ( $P$. uncinata, $P$. sylvestris) above that level; the spread of the beech began during this period and was accelerated by human activities (such as stock breeding, fire, lumber) (Galop, 1997; Galop and Jalut, 1994).

During the Middle Ages, the Upper Ariège was divided into feudal domains, whose wealth was based on the metallurgy industry. The Barony of Chateau-Verdun, including the Aston valley, was the leading domain, possessing six iron mines during the seventeenth century. Aston was one of the major "iron valleys" of the Ariège, alongside the Vicdessos, and had great wealth because of its large forest resources (Bonhôte and Fruhauf, 1990; Bonhôte, 1993). Charcoal production was documented very early: a charcoal kiln situated at $1700 \mathrm{~m}$ in the upper valley was dated back to the eighth century, revealing that exploitation of most of the forest was as early as the early Middle Ages. During this period, forest exploitation seems to have been based on periodic clear cutting with a cycle duration of probably 80 to 100 years; the impact is easy to see on the pollen diagrams (Galop, 1997; Galop and Jalut, 1994). As early as the thirteenth century, feudal forest guards controlled the forests and prevented their exploitation by other communities. Such silviculture did not exhaust the woodlands and the vegetation seems not to have changed until the end of the Middle Ages (Bonhôte, 1993; Verna, 1994).

A synthetic reconstruction of the landscapes of the Aston massif during the fourteenth and fifteenth centuries, at the start of the expansion of metallurgy (Bonhôte and Vernet, 1988; Bonhôte and Métailié, 1992; Bonhôte, 1993 ) is presented in Figure 19.5. The limits on the map were extrapolated from seventeenth century forest archives, land survey of charcoal kilns and anthropological analysis, which shows the extent and composition of the ancient forests. The cultivated lands of the villages were limited to the lower slopes of the Ariège and to the entrance of the Aston: cultivatable lands are restricted in the massif, and the upper valley was never settled, except some barns and slash-and-burn cultivation. Most of the forest was beech-fir, covering the northern slopes of the massif and both sides of the Aston valley up to 1700 to $1800 \mathrm{~m}$. Oak woodlands were present in the dry and rocky parts of the valley. During these times, the whole of the upper slopes and the plateau were covered by pine woods ( $P$. uncinata and $P$. sylvestris) mixed with fir and birch. The forest-line was at $2200 \mathrm{~m}$ and the tree line reached $2350 \mathrm{~m}$; these limits had not been modified by pastoralism and were linked to biogeographic factors (winds, avalanches, snow).

From the seventeenth century, the growth of metallurgy began to modify the landscape of the Aston. The intensification of charcoal production endangered woodlands regeneration, especially in the fir stands. In the same period, pastoral pressure increased on prairies and woodlands, linked to the growing of population and stocks. During the eighteenth century and the beginning of the nineteenth century, the fall in profitability of the metallurgy provoked the "iron master" of Gudanes to open his domain to pastoral use, for local or transhumant flocks. The villages in the Ariège valley had abundant grasslands on the lower sunny slopes, but lacked mountain pastures, and needed the use of the wide spaces of Aston massif. The sylvo-pastoral landscape 


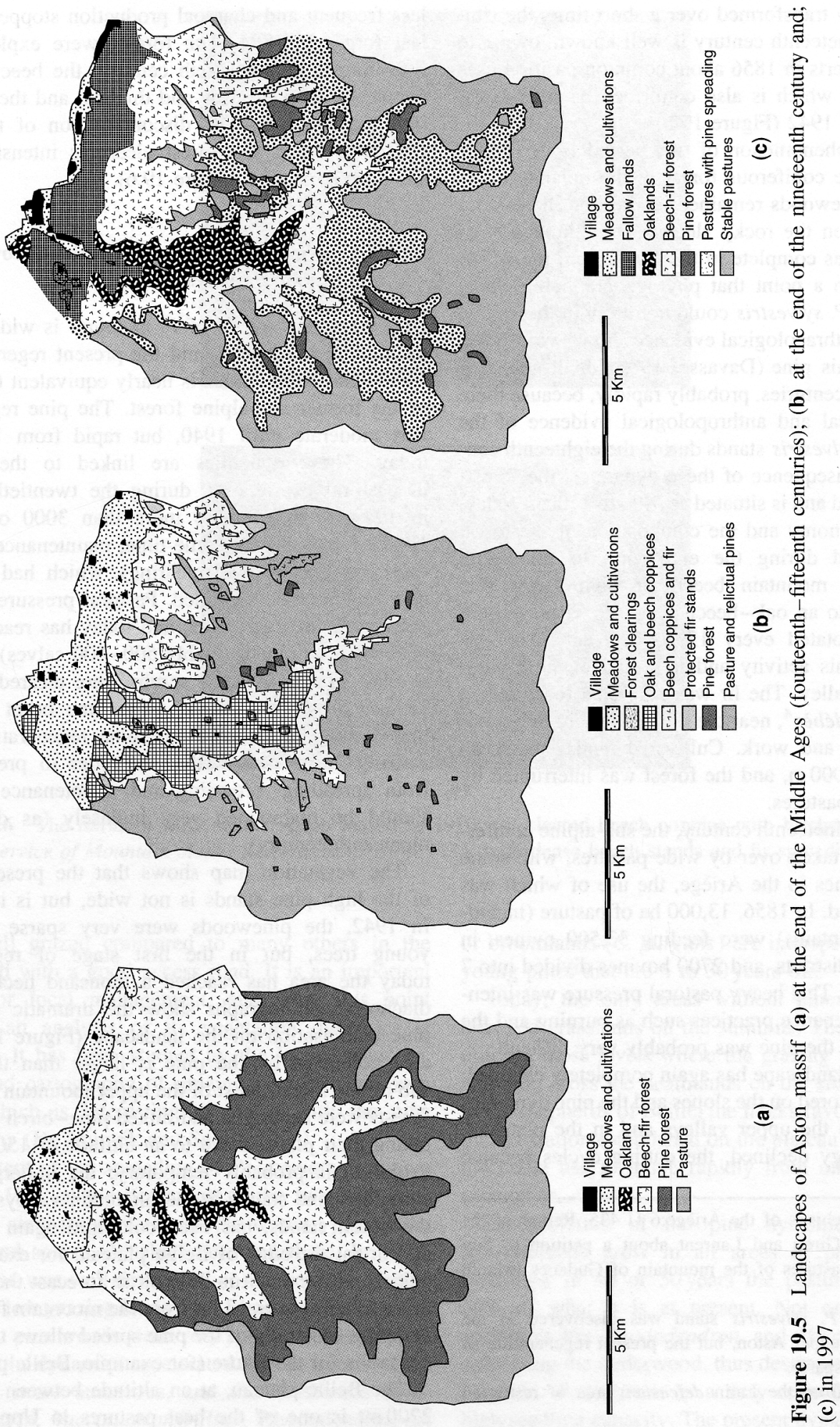


was completely transformed over a short time; the situation in the nineteenth century is well known, owing to a report of experts in 1856 about common pastoral uses in the domain, which is also confirmed by later aerial photographs of 1942 (Figure 19.5) ${ }^{2}$.

The major phenomenon of this period is the disappearance of the coniferous forest in the uplands. Only some relict pinewoods remained, mainly on the plateau of Beille and on the rocky slopes. The elimination of $P$. sylvestris was complete in the Massif and the whole Ariège, to such a point that phytogeographers believe today that the $P$. sylvestris could not grow in the valley, even though anthracological evidence shows widespread incidence of this pine (Davasse, 1993). It disappeared during the last centuries, probably rapidly, because there is archaeological and anthropological evidence of the remaining $P$. sylvestris stands during the eighteenth century $^{3}$. As a consequence of these dynamics, the forestline has dropped and is situated at 1400 to $1700 \mathrm{~m}$ today.

The physiognomy and the composition of the forest totally changed during the eighteenth to nineteenth centuries. The mountain beech-fir high forest was transformed into an oak-beech coppice, where cutting for charcoal rotated every 12 to 25 years. Oak was favoured for this activity and it spread on both sides of the Aston valley. The fir was restricted to protected stands, named débès ${ }^{4}$, near the villages where they were easy to watch and work. Cultivated lands spread up the slopes to $1000 \mathrm{~m}$, and the forest was interrupted by meadows and pastures.

During the nineteenth century, the sub-alpine coniferous forest was taken over by wide pastures, with some of the richer ones in the Ariège, the use of which was strictly regulated. In $1856,13,000$ ha of pasture (including rocky mountains) were feeding 33,500 ovines, in 19 permanent districts, and 2700 bovines divided into 7 moving droves. This heavy pastoral pressure was intensified by maintenance practices such as burning and the regeneration of the pine was probably very difficult.

The present landscape has again completely changed: the forest is restored on the slopes and the pine dynamics are dramatic in the upper valleys and in the plateaux. When metallurgy declined, the cutting cycles became

\footnotetext{
${ }^{2}$ Departmental archives of the Ariège: $6 \mathrm{U}$ 435. Report of the experts Bayard, Girou and Laurent about a petition to buy the forests and pastures of the mountain of Gudanes (March $26,1856)$.

${ }^{3} \mathrm{~A}$ small relict $P$. sylvestris stand was discovered in the Quioulès valley, upper Aston, but the present regeneration of this pine is very sparse.

${ }^{4}$ Débès, Devèze:from the Latin defensum, area of restricted uses.
}

less frequent and charcoal production stopped with the last forge, in 1884. The forests were exploited very little during the twentieth century; the beech and oak coppices began to grow and thicken, and the fir spread into the coppices. The discontinuation of the use of cultivated lands and forest clearings intensified these dramatic dynamics (Figure 19.6).

\subsubsection{Pine colonisation on the plateau: towards the end of summer pastures}

At present, the spread of $P$. uncinata is widespread in the mountain pastures, and the present regeneration of woods and sparse pines is nearly equivalent to the area of the former sub-alpine forest. The pine regeneration was moderate until 1940, but rapid from 1950 until today. These dynamics are linked to the decrease in pastoral exploitation during the twentieth century: in 1949, there were no more than 3000 ovines and 1000 bovines. At the same time, maintenance practices (burning, undergrowth clearing), which had restricted pine regeneration, declined. Pastoral pressure has risen during the last few years, and today has reached 1800 adult bovines (and probably 500-600 calves) and 5300 ovines. Some Juniperus scrubs were cleared, and two heather fires have, at the same time burnt 30 ha of pine stands. In spite of this, pine regeneration is not slowing and it seems that, in order to prevent pine from spreading, browsing and maintenance practices should be maintained very intensely (as during the nineteenth century).

The vegetation map shows that the present spread of the high pine stands is not wide, but is increasing. In 1942, the pinewoods were very sparse stands of young trees, but in the first stage of regeneration today the area has reached a thousand hectares. The diachronic photographs show the dramatic impact of pine colonisation on the landscape (Figure 19.7). The area colonised by the pine is larger than the former sub-alpine forest: most of the upper mountain beech-fir forests were destroyed and mixed pine-birch stands are taking their place, down to an altitude of $1500 \mathrm{~m}$. This evolution is probably temporary: the undergrowth of some old pine stands in the mountain valleys, close to the beech stands, has been colonised again by beech and fir (at the edge of Beille plateau, for example, see below). However, it is difficult to forecast the speed of this evolution in areas far from the mountain forest. The mapping and study of the pine spread allows us to build scenarios for the future (for example, Beille plateau).

The Beille plateau, at an altitude between 1600 and $2200 \mathrm{~m}$, is one of the best pastures in Upper Ariège 


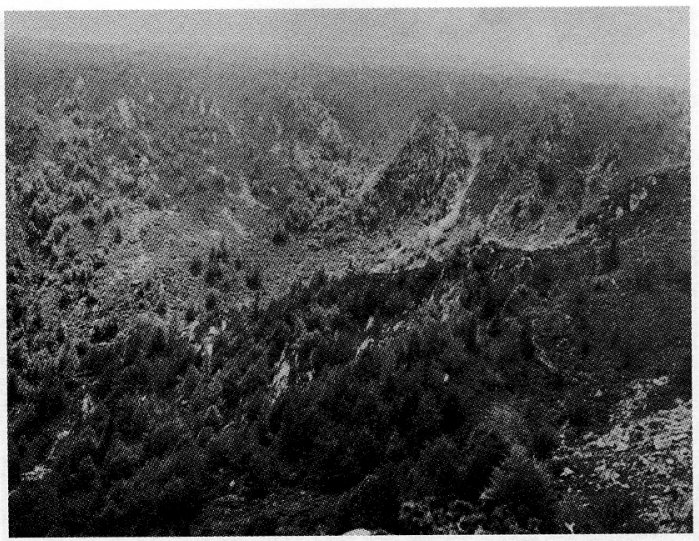

(a)

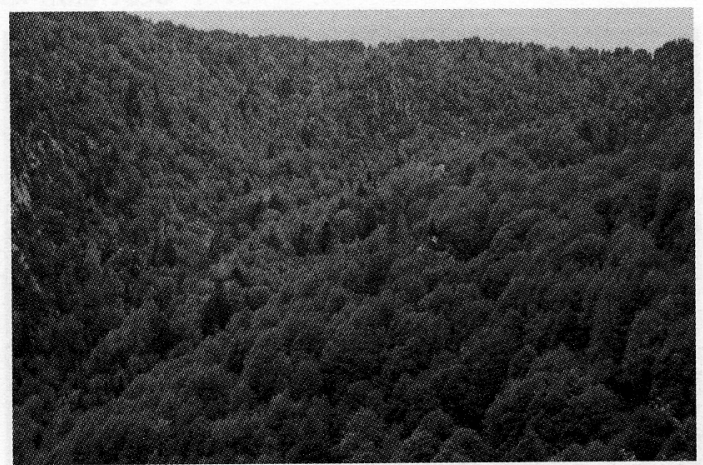

(b)

Figure 19.6 The northern slope of the Aston massif in 1910: (a) cleared beech coppice with birches, firs and pines (Source: Service of Mountain Slopes Restoration); (b) in 1985, with dense beech stands and fir spreading (Source: J.P. Métailié)

today, well grazed compared to many others in the valley, and with a good access road. It is an important pasture for local management, and from this point of view, an analysis of its vegetation dynamics is important. It has been studied by the local agronomic service and cartography of grazing potential has been drawn, which is interesting to match with the pine cartography (De Munnik and Sebill, 1995).

The extent of the spreading of $P$. uncinata is shown in Figure 19.7: at the beginning of the twentieth century there were some woods on the western part of the plateau, and sparse old pines here and there. In 1942, colonisation was well developed on the northern slopes, and in the low grazing lands with Rhododendron ferrugineum, but pine woods were very sparse. Between 1942 and 1997, the dynamics accelerated. Fertile trees became more and more numerous, and the heathlands (Calluna vulgaris, Vaccinium myrtillus, Rhododendron sp) or broomlands (C. purgans) are interspersed with some young pines that are 5 to 30 years old.

Today, the only areas without pines are the wellbrowsed grasslands on the summits. The cattle concentrate on those levels where the grazing value is higher, and only cross the heathlands on the slopes. According to the shepherds of Beille, the flocks favour the tracks of the ski station established on the plateau in 1989, which the cattle use to move rapidly from one good pasture to another.

Extrapolation of the pine dynamics is possible: if woodlands grow in all areas of present-day pine seedlings, in 40 or 50 years the pasture will only be $20 \%$ of what it is at present. Not only is the pine spreading but Rhododendron and Vaccinium are also colonising the underwood, thus destroying the grassland resource. $P$. uncinata is a very resistant species with high seedling capacity. The present dynamics show that, 


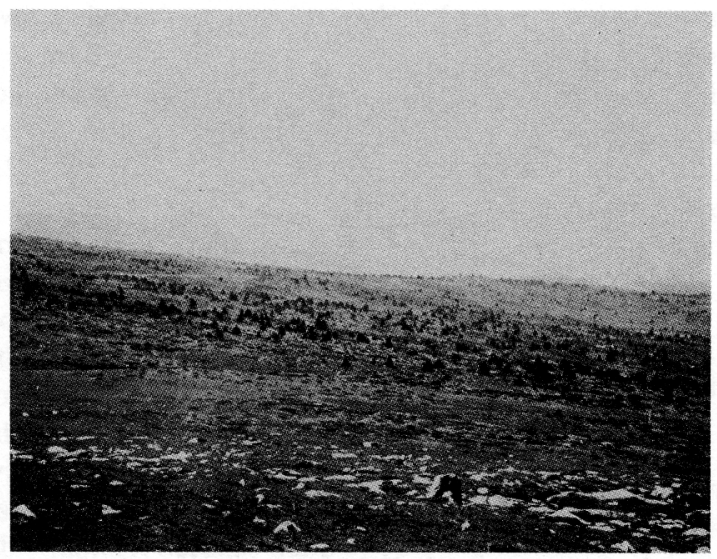

(a)

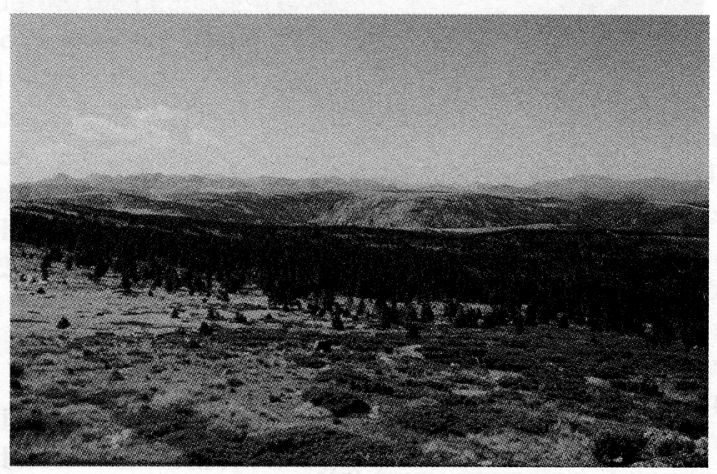

(b)

Figure 19.7 The plateaux of the Aston massif (a) in 1910 (Falgarouse, $1900 \mathrm{~m}$ ) with pastures and relict sparse pines (Source: Service of Mountain Slopes Restoration); (b) in 1985 with pine spreading and degradation of pastures by Juniperus and Rhododendron (Source: J. P. Métailié)

except for the tops of the mountains, cattle and sheep flocks cannot stop the pine colonisation by browsing and trampling alone to maintain the grazing resource. The short-term maintenance of pasture implies intense management practices such as the cutting of pines, and the clearing and burning of heathlands.

In Ariège, these pine dynamics are restricted to the Aston and Ax valleys. In the nearby valley of Vicdessos, paleoecological studies show that the pine woods have been important until the Middle Ages, but that their total deforestation is now preventing the pine from spreading. Similar pine dynamics are encountered in the central Pyrenées, especially in the upper valleys of Neste and Gave de Pau (Probst and Baudière, 1984). But, on the contrary, in the western area, in the Atlantic and wet mountains of the Couserans, the pine is very sparse and the upper forest limit is the stable border of the beech-fir-birch woodlands.
In the Aston example, the history of the forest since the seventeenth century shows a rapid change, either of deforestation or of afforestation. In spite of the apparent "wilderness" of the upper Ariège, the present mountain landscapes are very recent and fugitive. In this case, the $P$. uncinata is the main driving factor and sign of landscape mobility, and its role is greater in the Catalan mountains.

\subsection{RECENT DYNAMICS OF PINUS UNCINATA IN A CULTIVATED HIGH VALLEY (THE GARROTXES)}

\subsubsection{The study area}

The Garrotxes are situated on the central axis of the Eastern French Pyrenées, belonging to Haut-Conflent, on the southern side of Madrés massif (Figure 19.1). 


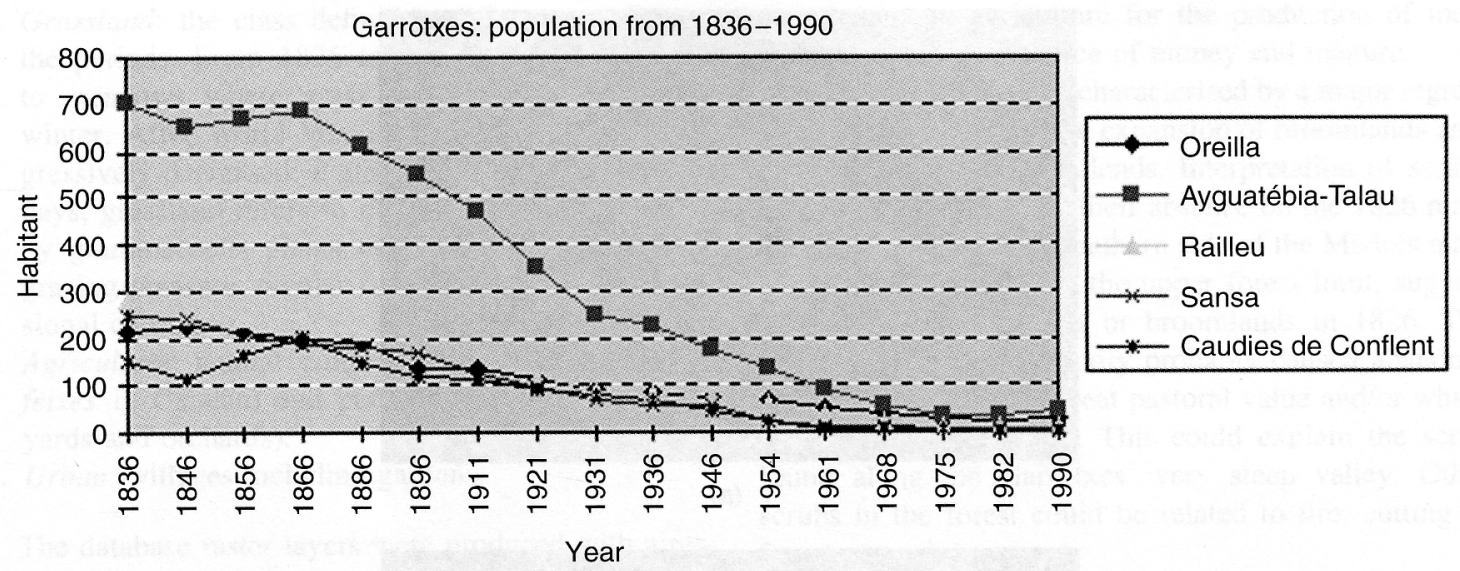

Figure 19.8 Demographic trends from 1836-1990

The catchment is 8.570 ha and composed of five municipalities (Ayguatébia-Talau - S, Caudiès de Conflent - SW, Oreilla - SE, Railleu - W et Sansa - N). Located between the Cerdagne, the Capcir and the Têt valleys, Garrotxes has a triangular form, reaching MontLouis (SW), Olette (SE) and the Madrés mountains (N). The Catalan word Garrotxes means rough land; the land is poor, rocky and steep with difficult access. The basin is drained by the Cabrils river flowing north-south through the main valley and in the lower part northwest-south-east, flowing into the Têt river near Olette at the south-east extremity. The confluence of the rivers is at the lower most point $(650 \mathrm{~m})$ while Madrés mountain in the north end culminates at $2469 \mathrm{~m}$. The right bank of the Cabrils is formed by a smoother relief of granitic basins. The majority of forests and terrace cultivation is situated on this bank, while the left bank of the Cabrils river has regular and steeper slopes formed by schists, which are used as (mountain) summer pastures.

The variation of altitude, which ranges between 700 and $2400 \mathrm{~m}$, with its mode at $1800 \mathrm{~m}$, explains the climatic gradient of the Garrotxes. The Cabrils valley is an area of Mediterranean influence in the centre of the eastern Pyrenees where the temperature decreases and precipitation increases from the south-east to the northwest. The climate is continental, characterised by long and cold winters (snow cover from the end of November to the end of March) and short, hot and dry summers.

The current vegetation is composed of forests, pasture and grassland. P. uncinata is the dominant tree, forming large forests particularly in the western (granitic) part. The upper forest limit is at about $2100 \mathrm{~m}$, while isolated patches reach $2250 \mathrm{~m}$ near Madrés. The warmer and lower slopes are also covered by formations of $Q$. ilex and $Q$. pubescens. Pasture is common on the left side of Cabrils, in little sunny areas and on the bottom of the valley. Lower broomlands are characterised by $C$. vulgaris and Juniperus communis, whereas, at higher altitude Genista purgans becomes dominant.

The population of Garrotxes decreased from 1598 inhabitants in 1836 to 94 in 1990 . However, by 1946 the population was already reduced by a factor of 4 compared to 1836 (Figure 19.8). This means that the most significant vegetation dynamics occurred in the first period of this analysis (1826-1942). The later periods (1942-1962-1995) are at the end of the evolutionary cycle.

In this area, as in most of the mountainous area in the eastern French Pyrenees, the demographic pressure reached a maximum in the first half of the nineteenth century, with intensive agricultural and pastoral land use. The traditional agricultural and pastoral economy was characterised by a high degree of autarky, subsistence cereal production and stock farming. As far back as 1830 to 1840 , a demographic regression in the rural depopulation began. This was emphasised by the railway connection opened in 1911 and is associated with economic changes and notably the insertion in a cash economy.

Rural depopulation led to a progressive abandonment of terrace cultivation. The terraces reverted to meadows, grasslands or broomlands. The reduction of sheep and bovine population, and the increasingly extensive pastoral resource management, allowed the spread of shrubs (especially from field hedges) and recolonisation by $P$. uncinata on grasslands and broomlands (Figure 19.9). The vegetation dynamics are thus producing a more uniform environment in which the forest is closing up, except for local openings by woodcutting or fires. 


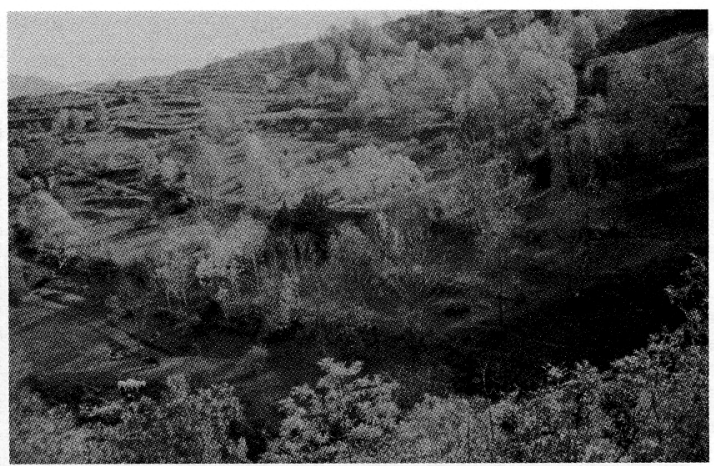

(a)

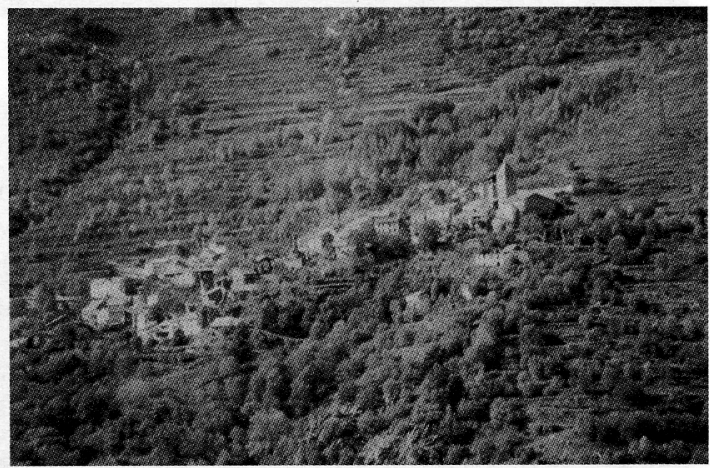

(b)

Figure 19.9 Examples of vegetation dynamics in the surrounding areas of Ayguatébia: (a) recolonisation by $P$. uncinata on former terrace cultivation in the upper part of the village environs and broomlands becoming scrubs in the foreground; (b) hedges of the formerly cultivated terraces currently used as grassland near Monocles (SW); bush spreading starts from the hedges gradually reducing the usable land

\subsubsection{Methodology}

The analysis of the landscape dynamics was based on an Idrisi GIS combined with Excel for the spatial and relational databases and Volumm4D for image processing.

Four periods with available land-use data were studied: 1826, 1942, 1962 and 1995. The Napoleonic land register is the first large-scale reliable cartographic document, which allows us to distinguish different land uses (forest, pasture, grassland and cultivation), for 1826. Land-use maps for 1942, 1962 and 1995 were produced from black and white aerial photographs.

A Digital Elevation Model (DEM) was produced and used to derive maps of slope and aspect. Other cartographic information included location of villages, networks of roads (in 1826 and in 1995), hydrology, municipalities, the recognisable extent of terrace cultivation (not necessarily cultivated) in 1942, the national forests and a very incomplete cartography of fires. Agricultural statistics were inaccessible because of data protection due to the limited number of farmers involved. The geological map is poor; soil and geomorphology maps do not exist.

The legend of the land-use maps took account of the heterogeneity of sources (land-register and aerial photographs) and was consequently rather rough. However, it allowed the following time-series analysis:

\section{Forest: dense woods.}

2. Scrub: intermediate class between forest and broomlands that includes broomlands with many bushes and isolated trees or groups of trees. This class appears only after 1942 because the 1826 land register did not include this information.

3. Broomlands: pastureland, particularly summer mountain pastures characterised by G. purgans and J.communis. 
4. Grassland: the class definition differs according to the periods. From 1826 to World War II, it refers to meadows where grass was cut for animals in winter. After World War II, such management progressively decreased; it stopped in the 1980s. These days, grassland refers to pastures mostly dominated by graminaceous plants managed by fencing, high grazing pressure, regular fire management and occasional cutting.

5. Agriculture: annual cultivation on terraces (called feixes in Catalan) and permanent cultivation (vineyards and orchards).

\section{Urban: villages including gardens.}

The database raster layers were produced with a resolution of $19 \mathrm{~m}$ ( 29 pixels per ha). Time-series analysis was performed by overlaying the four land-use layers. In order to take into account the possible sources of error (land register, interpretation of aerial photographs, digitising, pixel resolution, etc.), the dynamics observed on areas less than 1 ha (29 pixels) were not considered, giving a total area of 8570 ha. Owing to the stability of the urban areas and the fact that the scrub class appeared in 1942 only, there were theoretically 500 transition possibilities. In fact, about 300 different dynamics were observed, of which 189 exceeded 1 ha. The total extent of these 189 significant dynamics accounted for 99.5\% of the Garrotxes area.

A Principal Component Analysis (PCA) was applied to all layers to compute autocorrelation between parameters and to point out their influence on land use.

\subsubsection{Land-use evolution since the early nineteenth century}

The land-use maps of 1826, 1942, 1962, 1995 are shown in Figure 19.10. Land use in 1826 reflected a peak exploitation of land resources. The smallest increase of population had direct repercussions on the environment particularly in terms of the extension of the cultivated areas. Because of the Garrotxes topography, the area suitable for cultivation is located on the right-hand side of the Cabrils River, in granitic basins formed during the last glaciation. The steepness of the slopes requires the construction of feixes (terraces) to support agricultural activity. Farmers cultivated poor cereals such as rye, barley, a small amount of oats and potatoes here and there. Agricultural activity also included fodder crops (winter food) for cattle. The rocky, poor soils required biennial crop rotation. In the most Mediterranean part of the Garrotxes (the surroundings of Oreilla, $850 \mathrm{~m}$ ) vines and fruit trees such as apricots were cultivated. Stock farming, based on transhumance, was a necessary complement to agriculture for the production of meat and wool, and as a source of money and manure.

Land use in 1942 was characterised by a major regression of arable land and an expansion of broomlands and, to a lesser degree, woodlands. Interpretation of scrubs was difficult because of their absence on the 1826 map. The large scrub on the southern side of the Madrés massif, and its proximity to the upper forest limit, suggest a classification as forest or broomlands in 1826 . The decrease of pastoral activity probably caused abandonment of areas without great pastoral value and/or which were difficult to access. This could explain the scrub found along the Garrotxes' very steep valley. Other scrubs in the forest could be related to fire, cutting or forest extension.

Arable land drastically reduced in the first period, and continued to contract until 1962, extending the grassland. Forests and scrub began to spread to the detriment of broomlands. These changes corresponded to an increasingly simplified land-use pattern.

In 1995, arable land almost disappeared in the Garrotxes landscape. Grassland had continued to regress. In this last period, the most important change was the regression of broomlands to the advantage of scrubs and forests. Landscape homogenisation reached a maximum.

The land-use statistics are reported in Table 19.1. It should be noted that an almost complete disappearance of cultivated land occurred during the period 1826 to 1942 , with a reduction of $86 \%$ of the original 2063 ha. The regression of agricultural fields continued from 1962 to 1995; grassland also regressed constantly, reducing this class from 407 ha to only 84 ha in 1995. A contrasting evolution was observed in the case of broomlands: during the first period, broomlands expanded by $10 \%$ of Garrotxes, some 847 ha. Subsequently, a regression started in 1942 and speeded up from 1962. A total of 1246 ha of broomlands was converted into scrubs or forest and in 1995 they covered 400 ha less than in 1826 (a loss of $4.6 \%$ in terms of the whole Garrotxes' area). The forest showed a total gain of $20 \%$, half of this during the last period. Compared to 1826 , forests expanded to 1676 ha by $70 \%$. Scrubs also increased from 615 ha in 1942 to 1100 ha in 1995 .

The peaks of land-use dynamics for the different classes suggest a classic evolutionary scenario for the eastern Pyrenees. The first step is the abandonment of cultivation on terraces and transformation into grassland followed by a succession to broomlands. At the same time, the decreased management of broomlands caused the reduction of scrub to the advantage of forest formation. Stable areas were mostly broomlands and 

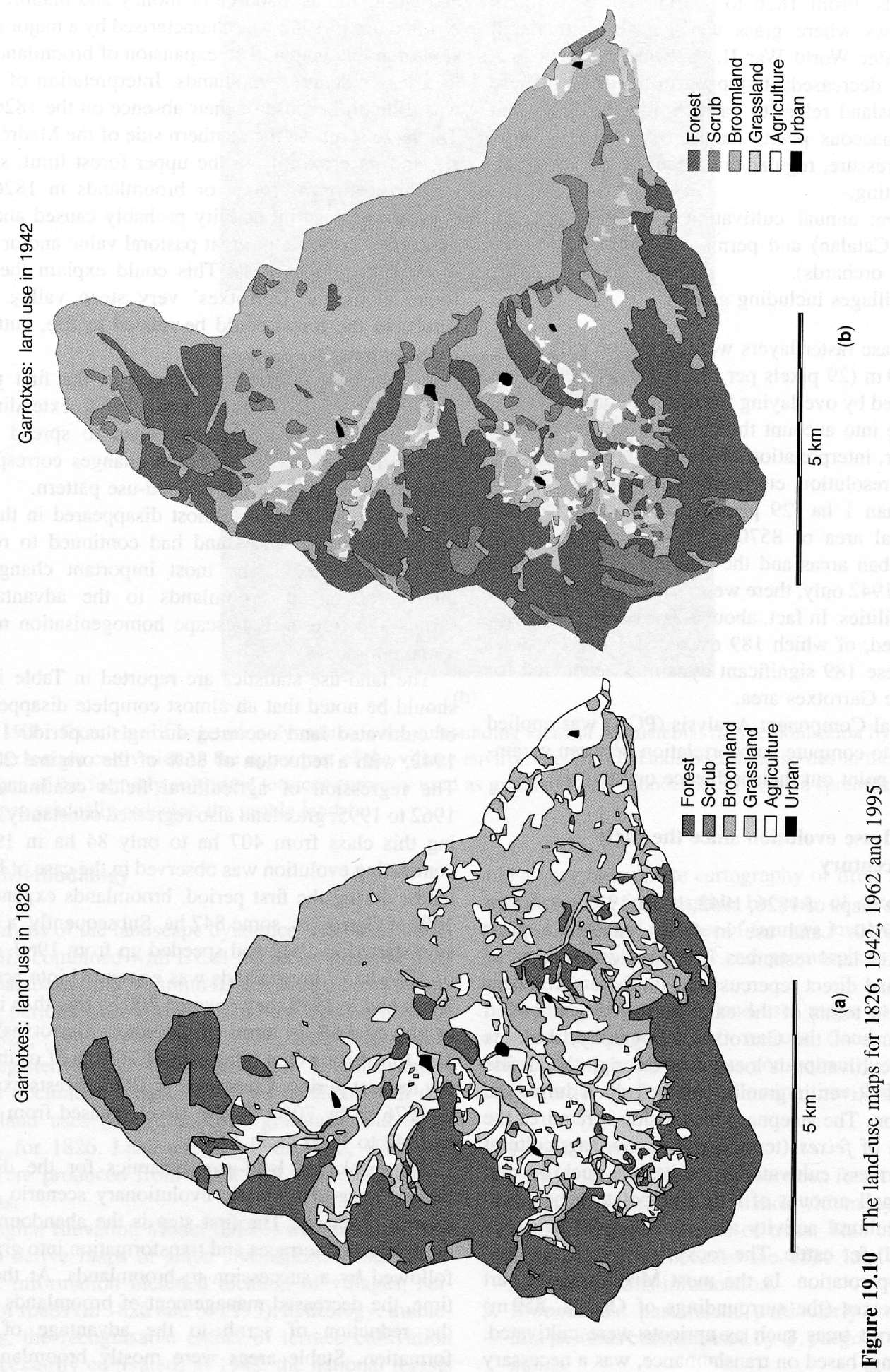

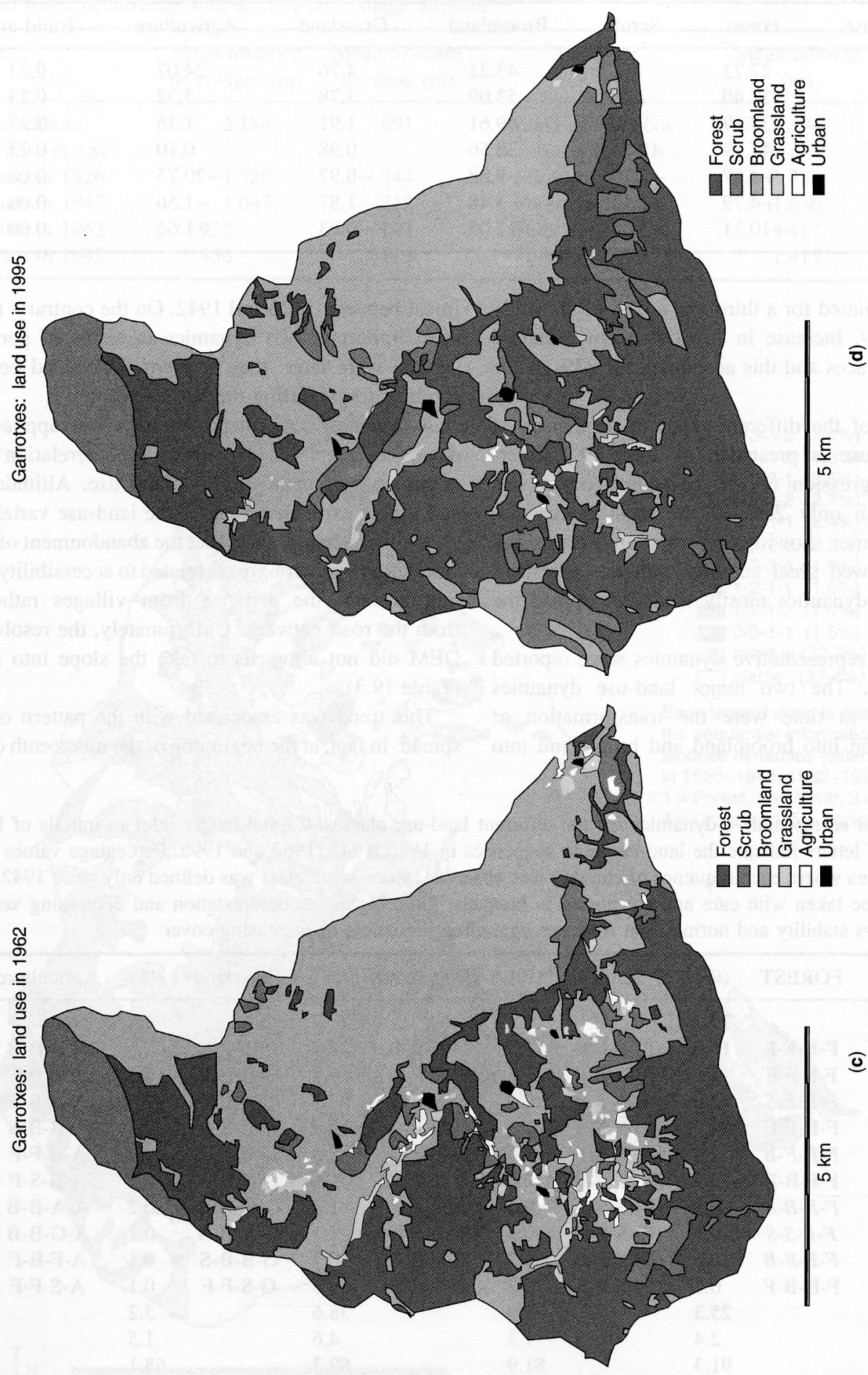

oิ

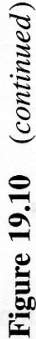


Table 19.1 Land-use area and change between 1826 and 1995

\begin{tabular}{lrrccrc}
\hline Year $\backslash$ land use & Forest & Scrub & Broomland & Grassland & Agriculture & Build area \\
\hline 1826 & 27.73 & & 43.21 & 4.76 & 24.07 & 0.23 \\
1942 & 32.40 & 7.18 & 53.09 & 3.78 & 3.32 & 0.23 \\
1962 & 37.19 & 9.30 & 49.61 & 1.91 & 1.76 & 0.23 \\
1995 & 47.29 & 12.84 & 38.56 & 0.98 & 0.10 & 0.23 \\
$1826-1942$ & +4.67 & +7.18 & +9.88 & -0.97 & -20.75 & 0.00 \\
$1942-1962$ & +4.79 & +2.12 & -3.48 & -1.87 & -1.56 & 0.00 \\
$1962-1995$ & +10.11 & +3.54 & -11.05 & -0.93 & -1.66 & 0.00 \\
\hline
\end{tabular}

forests and accounted for a third and a fifth of the study area respectively. Increase in vegetation cover started mostly from terraces and this accounted for $83 \%$ of the total change.

A summary of the different types of sequences of changing land use is presented in Table 19.2. Interestingly, the regression of the vegetation cover was exceptional, with only $20 \%$ of the most representative forest dynamics showing deforestation. Forests and broomlands showed great stability, whereas grassland and agriculture dynamics mostly tended to spread the forest cover.

The 10 most representative dynamics were reported in Figure 19.11. The two major land-use dynamics occurring early in time were the transformation of terrace cultivation into broomland and broomland into forest between 1826 and 1942. On the contrary, the next most important two dynamics in terms of percentage surface were later: they concern broomland becoming scrub or forest during the last 23 years.

A principal components analysis was applied to all database layers to investigate the correlation of the environmental parameters to land use. Altitude, slope and aspect explained most of the land-use variability.

An interesting point is that the abandonment of terrace cultivation was strongly correlated to accessibility, taking into account the distance from villages rather than from the road network. Unfortunately, the resolution of DEM did not allow us to take the slope into account (Table 19.3).

This trend was associated with the pattern of forest spread. In fact, at the beginning of the nineteenth century,

Table 19.2 Most representative dynamics for the different land-use classes. Capital letters refer to initials of land-use classes. Series of letters indicate the land-use time sequences in 1826, 1942, 1962 and 1995. Percentage values refer to total Garrotxes area where each sequence of changes was observed. Since scrub class was defined only since 1942, former land use should be taken with care and are placed in brackets. Italic highlights deforestation and decreasing vegetation cover. Bold shows stability and normal font indicates aggrading sequences of increasing cover

\begin{tabular}{lcrlrlrlrrr}
\hline & FOREST & $(\%)$ & Scrub & $(\%)$ & Broomland & $(\%)$ & Grassland & $(\%)$ & Agriculture & $(\%)$ \\
\hline Extent in 1826 & & 27.7 & & 7.2 & & 43.2 & & 4.7 & & 24.1 \\
& F-F-F-F & $\mathbf{1 6 . 0}$ & (F)-S-F-F & 1.9 & B-B-B-B & $\mathbf{2 0 . 4}$ & G-F-F-F & 0.6 & A-B-B-B & 7.9 \\
& F-S-F-F & 1.9 & (B)-S-F-F & 1.3 & B-F-F-F & 4.3 & G-B-B-B & 0.5 & A-F-F-F & 2.4 \\
& $F-F-F-S$ & 1.6 & (B)-S-S-F & 0.5 & B-B-B-F & 3.5 & G-B-B-F & 0.5 & A-B-B-F & 1.9 \\
Land-use time & F-B-F-F & 1.2 & (B)-S-S-S & $\mathbf{0 . 4}$ & B-B-B-S & 2.7 & G-G-B-B & 0.4 & A-B-B-S & 1.4 \\
sequences & $F-F-F-B$ & 1.1 & (A)-S-S-F & 0.4 & B-B-S-S & 2.3 & G-B-F-F & 0.4 & A-B-F-F & 1.3 \\
& F-F-B-F & 0.9 & (B)-S-B-F & 0.4 & B-B-F-F & 1.6 & G-F-B-F & 0.2 & A-B-S-F & 0.9 \\
& $F-F-B-B$ & 0.8 & (F)-S-S-S & $\mathbf{0 . 3}$ & B-S-F-F & 1.3 & G-G-G-B & 0.2 & A-A-B-B & 0.8 \\
& $F-B-S-S$ & 0.7 & (F)-S-S-F & 0.3 & B-B-S-F & 1.1 & G-A-B-B & 0.1 & A-G-B-B & 0.8 \\
& $F-B-B-B$ & 0.6 & (B)-S-B-B & 0.2 & B-F-B-F & 0.7 & G-B-B-S & 0.1 & A-F-B-F & 0.4 \\
& F-B-B-F & 0.5 & (F)-S-F-S & 0.2 & B-S-S-F & 0.5 & G-S-F-F & 0.1 & A-S-F-F & 0.4 \\
Total changes & & 25.3 & & 5.9 & & 38.6 & & 3.2 & & 18.3 \\
Residue & & 2.4 & & 1.3 & & 4.6 & & 1.5 & & 5.8 \\
Total & & 91.3 & & 81.9 & & 89.3 & & 68.1 & & 75.9 \\
changes/extent & & & & & & & & & & \\
\hline
\end{tabular}


Table 19.3 Relation between terrace abandonment and accessibility (mean distance to villages and road network in 1995) and forest occurrence with altitude and village distance

\begin{tabular}{|c|c|c|c|c|c|}
\hline Land use & $\begin{array}{l}\text { Mean distance } \\
\text { to villages }(\mathrm{m})\end{array}$ & $\begin{array}{l}\text { Mean distance } \\
\text { to roads }(\mathrm{m})\end{array}$ & Land use & $\begin{array}{l}\text { Mean altitude } \\
(\mathrm{m})\end{array}$ & $\begin{array}{l}\text { Mean distance } \\
\text { to villages (m) }\end{array}$ \\
\hline $\begin{array}{l}\text { Land use without } \\
\text { agriculture in } 1826\end{array}$ & 2.184 & 691 & $\begin{array}{l}\text { Land use without } \\
\text { forest in } 1826\end{array}$ & 1.594 & 1.863 \\
\hline Agriculture in 1826 & 1.328 & 344 & Forest in 1826 & 1.781 & 2.400 \\
\hline Agriculture in 1942 & 1.047 & 212 & Forest in 1942 & 1.650 & 1.939 \\
\hline Agriculture in 1962 & 932 & 143 & Forest in 1962 & 1.417 & 1.463 \\
\hline Agriculture in 1995 & 856 & 123 & Forest in 1995 & 1.415 & 1.463 \\
\hline
\end{tabular}

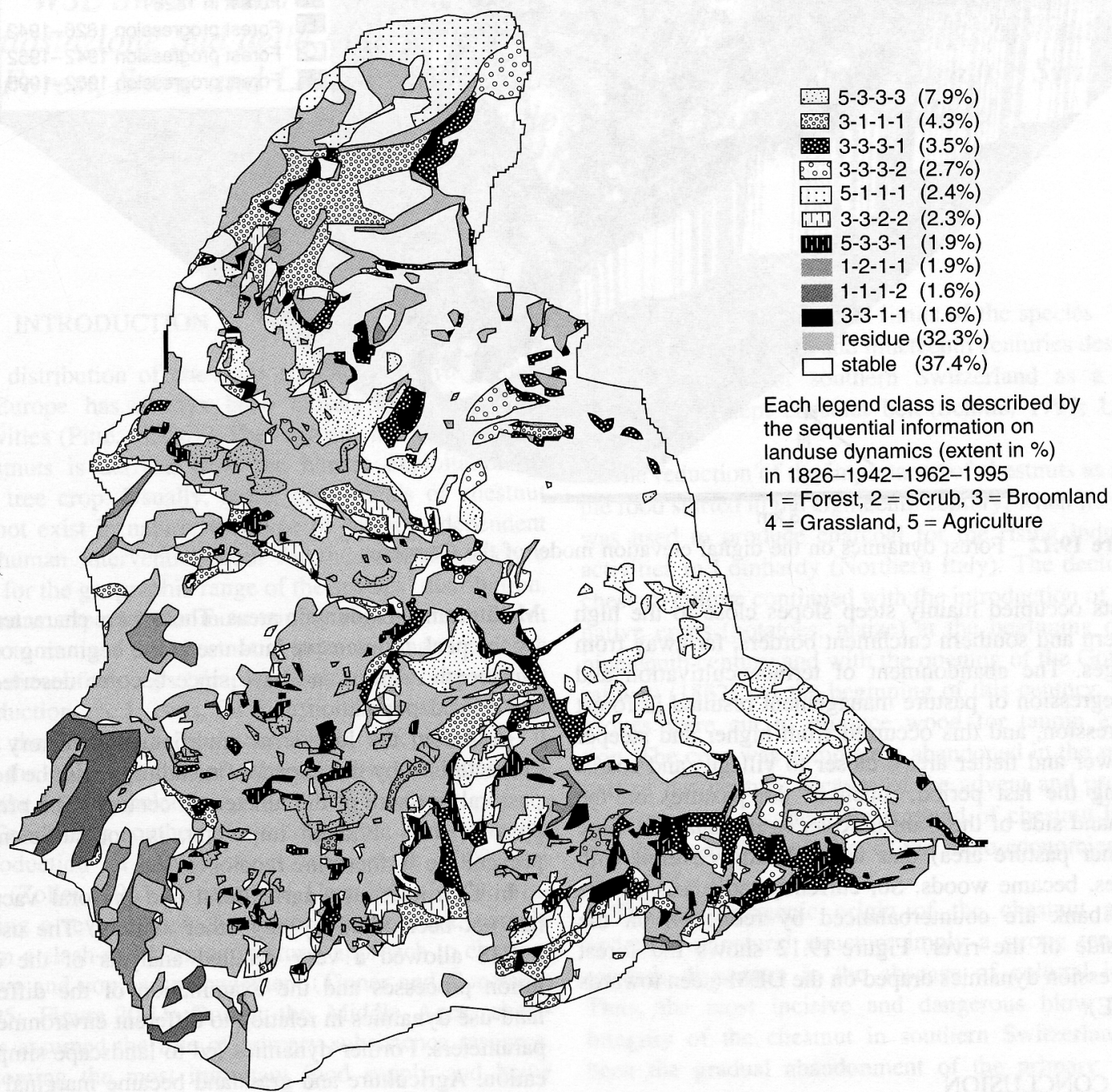

$T^{N}$

$5 \mathrm{~km}$

Figure 19.11 Results of the landscape dynamics analyses in the Garrotxes 


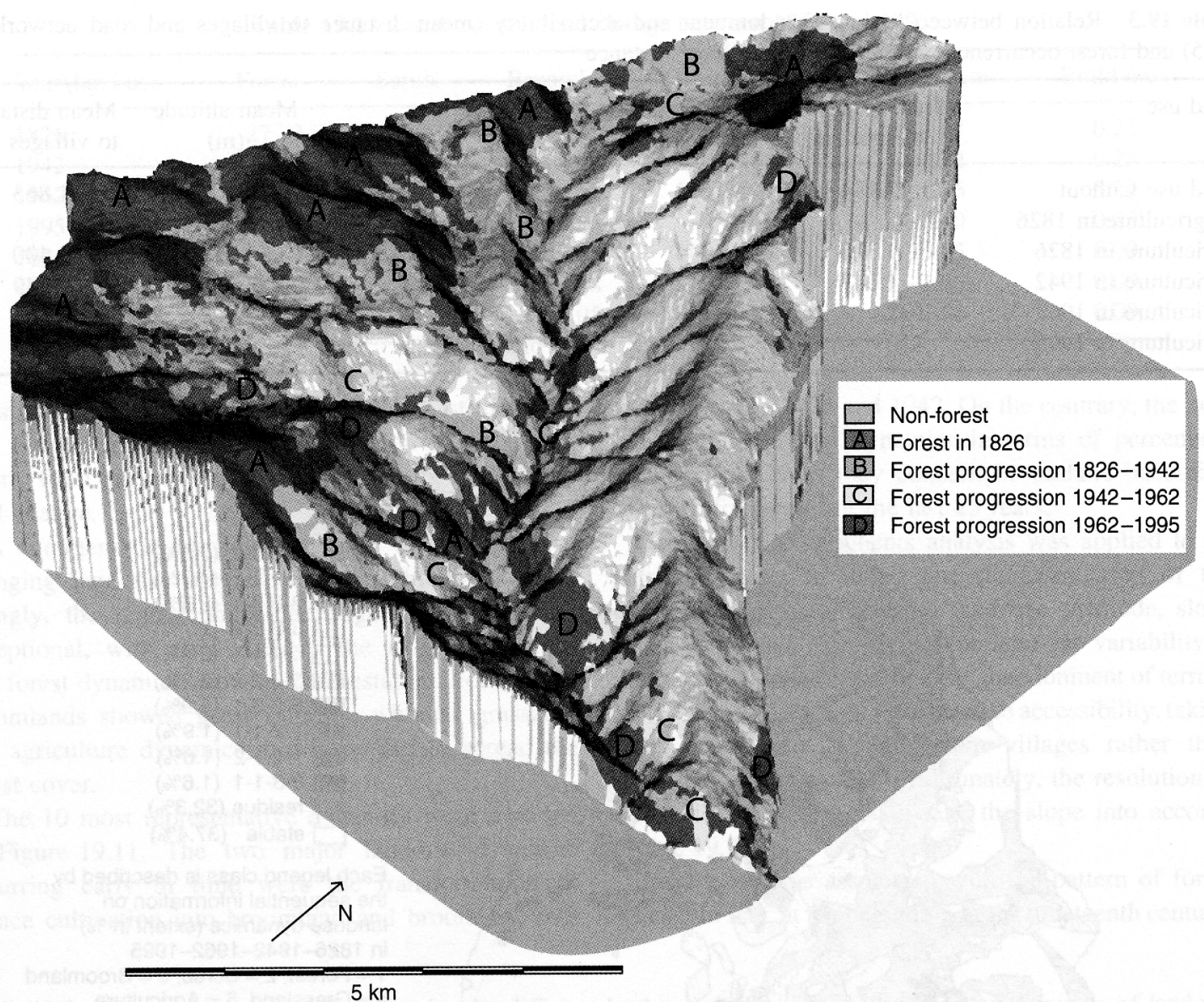

Figure 19.12 Forest dynamics on the digital elevation model of the Garrotxes

forests occupied mainly steep slopes close to the high western and southern catchment borders, far away from villages. The abandonment of terrace cultivation and the regression of pasture management resulted in forest progression, and this occurred from higher and steeper to lower and flatter areas, closer to villages and roads. During the last period, much of the pastures on the left-hand side of the Cabrils River (traditionally a large summer pasture area) that were already covered with bushes, became woods. So, currently, advances on the right bank are counterbalanced by reduction on the left side of the river. Figure 19.12 shows the forest progression dynamics draped on the DEM (seen towards the SE).

\subsection{CONCLUSION}

The vegetation dynamics in the Aston and the Garrotxes are typical examples of the transformation of western
Mediterranean mountain areas. These were characterised by the peak in intensive land use at the beginning of the nineteenth century and have since become deserted by the rural depopulation.

In Aston, the long-term environmental history was characterised by the impact of metallurgy and the heavy pastoral pressure of the nineteenth century. The present pastoral use, although important, is not sufficient to prevent the further pine recolonisation.

In Garrotxes, the agricultural and pastoral vacuum has not been filled by any other activity. The use of a GIS allowed a very detailed analysis of the evolution processes and the examination of the different land-use dynamics in relation to different environmental parameters. Former dynamics led to landscape simplification. Agriculture and grassland became marginal and the dynamics in the near future will depend on the intensity and kind of pasture management. This will be crucial for the broomland-forest balance. 